\title{
Plans identify indicators (water, soil and Industry) applicable in Ilam Dam basin water with emphasis on sustainable development
}

\author{
Karam KHALILI $^{1}$, Ali JAMSHIDI ${ }^{2}$, Esfandiar MOHAMMADI ${ }^{3}$ \\ ${ }^{1}$ Assistant professor in Ilam Islamic Azad University \\ ${ }^{2}$ M.A. student of strategic management, Ilam Islamic Azad University \\ ${ }^{3}$ Assistant professor, Ilam University
}

\begin{abstract}
The negligence of development impacts in recent decades has imposed serious problems to great projects due to inattention to the environment. To this end, a positive movement towards the assessment of strategic development effects has been triggered in recent years. This study aims to identify and prioritize executable development projects in the area of drinking water dam of Ilam with the priority of assessing environmental impacts. It is an applied study in terms of objective and a descriptive-analytical study in terms of method. The study population consists of two qualitative and quantitative sections. Experts who are familiar with related issues, problems and impacts of dam making projects constitute the first section while the second one covers specialists who are familiar with the drainage basin of dam. The samples of both sections were selected using purposive sampling method. Data was collected by questionnaire (both open-ended and close-ended questionnaires) and was analyzed using SPSS and Liserl. Finally, 9 important factors were identified as the main title of projects namely: 1) plant product projects, 2) livestock product projects, 3) water, soil and industrial projects, 4) veterinary medicine projects, 5) forest, pasture and watershed management projects, 6) promotion and exploitation projects, 7) economic association projects, 8) production cooperatives for providing agricultural engineering services and 9) job opportunities of agriculture sector. In addition, 82 development-titled projects were extracted to be studied in Ilam dam site.
\end{abstract}

Keywords: employment, executable projects, Ilam dam, sustainable development.

\section{Introduction}

If management is defined as the process of solving problem(s) to realize organizational targets in the best way through efficient of rare resources in an ever-changing environment, decision-making can be defined as the method of moving in a special route ending to an ideal target, which is deliberately selected among different available routes [Mehrghan, 2004]. Before 1961, planning and decision-making were easy to practice issues and prioritization was not the case as there were a limited number of executable projects on the one hand and restrictions on credits required for the projects were few on the other hand. Since economic revolution era, i.e. from the beginning of 1940s, huge investments have been made to finance water projects to be implemented because of increased demand for supplying safe drinking water arising from increased population, industry development and promotion and increase of agricultural products. The inherent limitation of Iranian water resources has been an 
important challenge of the country's water sector. The average precipitation of Iran is about $240 \mathrm{~mm}$ on annual basis. This corresponds to one third of global average and half of Asia continent. This implies that Iran is an arid and semi-arid country with northwestern and western regions with the highest precipitation. In a large area of eastern and southeastern regions of Iran, the average precipitation is less than 100mm on annual basis (Abbaspour, 1993). Northern and northwestern regions have the main water resources so that they possess $70 \%$ of high- quality water resources while $50 \%$ of areas in central, eastern and southeastern regions possess only $30 \%$ of water resources.

Considering the importance of rivers, dams and aquatic habitats as the most important aquatic ecosystems, the development of time and site requirements of rivers and aquatic ecosystems is of high importance in the process of developing and exploiting water resource plans in order to estimate demands based on real facts. In the sustainable development of developing countries in $21^{\text {th }}$ century, effective management of water resources, use of non-conventional resources (water recycling) and technology development were proposed as three pillars of sustainable development. Therefore, emphasizing environmental impacts, this study aims to identify and prioritize executable projects in Ialm dam.

\section{Literature of study}

\subsection{Factors threatening Iranian water resources}

Considering above discussions, one can argue that Iranian water resources are at risk. To evaluate this, this section briefly assesses the main influential factors of Iranian environment and water resources.

\section{A) Drinking and health consumption}

Both population and consumption are variables increasing continually. In recent years, Iran has experienced population growth. The global rate of demand for water is held in Iran for different consumption areas so that $71 \%$ of the renewable resources of water are being used in Iran. According to the prediction of 2021 horizon, Iran population will rise to 97.5 million, 81 million of whom will be city residents (Management and Planning Organization of Iran, 1999). If Iran population is considered approximately 100 million in 2021, the per capita renewable water resources will be $1300 \mathrm{~m}^{3}$. According to global standards, this lies inside critical boundary. Therefore, if the demand for drinking water is estimated to be 7.8 billion $\mathrm{m}^{3}$ in 2021 , about 2 billion $\mathrm{m}^{3}$ high quality water should be supplied as per current standards. This is a great challenge demanding great investments and developing special regulations as to the protection of water resources and monitoring them because of water pollution with different pollutants.

\section{B) Industry and service sectors consumptions}

Industry and service sectors have their own special place in both water consumption and water quality. Water consumption in the industry sector accounts for 1 billion $\mathrm{m}^{3}$ per year, 60-70 percent of which is being discharged to the environment as industrial wastewater. According to the reports of Iran Statistical Center in 2000, the majority of Iranian industries have been centralized in given regions of Iran. This has induced different environmental problems in the regions (Iran Statistical Center, 2003). According to the center, of all 
industrial workshops in Iran, 1302 workshops discharge industrial wastewater. Moreover, most workshops either lack modern technologies or wastewater treatment installations or, if have, their outlet wastewater is not refined correctly and does not satisfy standards. According to predictions, the increased water consumption in the industry sector will induce more sophisticated consequences. This, in turn, will require advanced and supplementary refineries. Since the industry of wastewater treatment benefits from economic subsidies, wastewater treatment is not practiced accurately and continuously and this is water, which is generally considered as the main subsidy. Iranian industry sector is weak in technology and its facilities are old. On the other hand, public sector is the owner of the main part of Iranian industry. Therefore, the likelihood of existing polluting industries, especially water polluting industries, is increased and this is another deficiency of this sector.

\section{C) Agriculture sector consumption}

The agriculture sector is the main consumer of water so that in 2001 it supplied its demand for water (account for $86 \%$ of harvested water resources) form surface waters and $54 \%$ from ground waters (environment and sustainable development office of the Ministry of Agriculture Jahad, 2003). On the other hand, chemical fertilizers and pesticides are not used optimally. Therefore, a main part of agricultural wastewater is discharged to water resources through rivers and drainages and this has resulted in contaminated and saline water resources [Nazari et al., 1997]. According to investigations, in the past two decades there was no considerable change in agricultural lands area so that from 1973 to the end of the last investigation, the growth of agricultural area was only $4.5 \%$. On the other hand, agricultural products had a considerable growth thanks to the use of chemical fertilizers, chemical toxins and benefiting from appropriate mechanisms. This has accompanied with many negative consequences including soil and water pollution.

In a paper titled "investigation of environmental impacts in irrigation and drainage networks" Sheibani (2013) concluded that the assessment of environmental impacts is a very effective technique for evaluating the effects of different sectors or activities on the components of the environment through understanding the environment and its importance. This helps planners to well know the status of natural environment of the studied region. Therefore, in addition to dam, itself, such considerations should be taken into account in the development projects [Sheibani, 2013, p 6].

In a paper titled "economic growth, human development and water pollution arising from the economic activities of the selected countries of the world", Dizaji and Gholaminezahd Dizgah (2011) concluded that economic growth accelerates the environment depletion. Therefore, economic growth and human development foster the environment depletion and pollution [Dizaji and Gholaminezhad, 2011, p17]. Ahmadi and Hajinezhad (2010), concluded in their paper titled "environment destruction: a hurdle in the way of sustainable development" that a country will not achieve sustainable development if it does not take environmental considerations into account. They argued that environmental assessments should be practiced in the execution of all projects [Ahmadi and Hajinezhad, 2010, p129].

In a paper titled "the economic analysis of the effects of demand management policies on water resource development plans" Karamouz, Eliasi and Ahmadinia (2008), concluded that environmental assessments should be always taken into account as an essential component of 
such plans [Karamouz et al, 2008, p. 156]. In November 1986, all aquatic animals from Ball in Switzerland to Netherlands coasts were died due to the discharge of mercury-contained substances.

The sinking or grounding of huge oceangoing oil vessels has imposed serious damages to sea life in recent years. In 1983, about 120 million liters pollutants were discharged in the U.S. waters due to 11000 contaminating accidents. The Global Bank "The world development indices" report on water pollution was published for two issues: a) the emission of organic water pollutants and b) the contribution of the industry sector to water pollution. The report emphasizes that in 1990, the emission of organic pollutants in Iranian water was $0.16 \mathrm{~kg}$ per day per labor and this value remained the same by 2003. Surprisingly, the emission of water pollutants decreased from 1990 to 2003 in many countries including China, the U.S., Russia, India, Japan, Germany and Brazil. According to the Global Bank, in 2003 food and beverage industry-induced pollutions accounted for the main part of contamination in all countries with Moldavia with the highest registered pollution so that Moldavian food and beverage industry was responsible for $98 \%$ of water pollution.

\subsection{Method of study}

This is a combined qualitative-quantitative study where encoding and descriptive-correlation techniques were applied in the qualitative and quantitative parts, respectively. It is an applied study in terms of objective. Considering the study nature, it has two types of population. The population of the qualitative part consists of experts and specialists who are familiar with water resources as well as agricultural, livestock and the industrial resources of the studied province. In the quantitative part, the population consists of 82 specialists who are specialized in the studied area (see below table). A total number of 8 experts were selected as the qualitative part population based on their proficiency in the qualitative and quantitative protection of the province water resources (members of water resource protection committee). In the quantitative part, purposive sampling technique was used and 82 experts were selected considering the limited number of experts in the studied area. In the quantitative part, the identified factors were approved using structural equations and Liserl. SPSS was used to rank the identified projects constituted by 9 main factors and 82 assessable projects. First, executable development projects in the drainage basin of Ilam dam were identified through interview. Then, the identified factors formed a conceptual model using encoding technique. In addition, the questionnaire of the quantitative part was developed using extracted joint codes and based on Likert 5-point scale. The content validity was approved using the opinions of specialists, adviser professor and consultant and others. Cronbach's alpha was derived to be 0.90

\subsection{Objectives}

\section{A) General objective}

Identification and prioritization of executable projects in the area of Ilam drinking water dam emphasizing environmental impacts 
B) Subsidiary objectives

1) Identification of executable agricultural projects in the area of Ilam drinking water dam emphasizing environmental impacts

2) Identification of executable livestock and plant product projects in the area of Ilam drinking water dam emphasizing environmental impacts

3) Identification of executable industrial projects in the area of Ilam drinking water dam emphasizing environmental impacts

4) Identification of executable forestry, posture and watershed management projects in the area of Ilam drinking water dam emphasizing environmental impacts

5) Identification of executable economic association projects in the area of Ilam drinking water dam emphasizing environmental impacts and

6) Prioritizing the above mentioned projects emphasizing environmental impacts.

\section{Data analysis}

Table 1: Propositions derived from interview (encoding)

\begin{tabular}{|c|c|c|}
\hline code & $\begin{array}{l}\text { Interview } \\
\text { no. }\end{array}$ & Executable project \\
\hline 100 & 1 & Construction and development of aquatic and dry land gardens \\
\hline 101 & 1 & Modification, replacement and renovation of gardens \\
\hline 102 & 2 & Production of certified seedling \\
\hline 103 & 2 & Construction of flower, vegetable and summer crops greenhouses \\
\hline 104 & 3 & improving, renovating and equipping greenhouses \\
\hline 105 & 3 & Production and collection of medicinal herbs and planting medicinal plants \\
\hline 106 & 5 & constructing, equipping and developing mechanized agricultural units \\
\hline 107 & 7 & Development of rice seedling bank and production of rice hybrid seed \\
\hline 108 & 7 & $\begin{array}{l}\text { Development of summer crops and rice seedling bank-production of vegetable and } \\
\text { summer crops hybrid seeds }\end{array}$ \\
\hline 109 & 8 & Construction of honey bee queen breeding units \\
\hline 110 & 8 & $\begin{array}{l}\text { Construction of silkworm breeding units-construction of mobile centers for milk } \\
\text { collection }\end{array}$ \\
\hline 111 & 1 & $\begin{array}{l}\text { Construction of complementary industries subsidiary to plant production units } \\
\text { including packing, preservation and freezing different kinds of cereals, vegetables, } \\
\text { citrus fruits, agricultural products, different fruit juices and cold storage facilities. }\end{array}$ \\
\hline 112 & 1 & Tannery and hide projects \\
\hline 113 & 1 & Beverage, non-natural (essence) fruit juice industries \\
\hline 114 & 1 & Wooden products industries \\
\hline 115 & 1 & Gas station \\
\hline 116 & 2 & Bitumen and asphalt industry \\
\hline 117 & 2 & Metal melting industry \\
\hline 118 & 2 & Confectionary and cookie industries \\
\hline 119 & 2 & Industrial poultry and livestock slaughterhouses \\
\hline 120 & 3 & Meat packing and meat products \\
\hline 121 & 3 & Production of compost out of municipal wastes \\
\hline 122 & 3 & Production of compost out of livestock dung \\
\hline 123 & 3 & Refining industrial oils \\
\hline 124 & 3 & Producing and refining edible oils \\
\hline 125 & 4 & Production of brick and ready-mix concrete products \\
\hline
\end{tabular}




\begin{tabular}{|c|c|c|}
\hline code & $\begin{array}{l}\text { Interview } \\
\text { no. }\end{array}$ & Executable project \\
\hline 126 & 4 & Production of building packed plaster and lime \\
\hline 127 & 5 & Production of plastic and rubber-made products \\
\hline 128 & 5 & Human medicine industry \\
\hline 129 & 6 & Livestock and aquatic animals medicine industry \\
\hline 130 & 6 & Vehicle part industries \\
\hline 131 & 7 & Vehicle rubber part industries \\
\hline 132 & 8 & Paint and chemical substance industries \\
\hline 133 & 8 & $\begin{array}{l}\text { Construction of complementary and processing industries subsidiary to livestock } \\
\text { products, cold storage facility, processing and packing different red meat, white meat } \\
\text { and dairy products }\end{array}$ \\
\hline 134 & 1 & $\begin{array}{l}\text { Construction of processing industries subsidiary to fishery industry including freezing, } \\
\text { processing and packing different fishes, shrimps and can products }\end{array}$ \\
\hline 135 & 1 & Cattle breeding project (less than 25 cattle) \\
\hline 136 & 1 & Cattle breeding project (more than 25 cattle) \\
\hline 137 & 1 & Egg-laying chicken breeding project (1000 chickens and more) \\
\hline 138 & 1 & Warm and cold water fish-breeding project \\
\hline 139 & 2 & Industrial Cattle breeding (100 cattle) \\
\hline 140 & 2 & Industrial Cattle breeding (200 cattle) \\
\hline 141 & 2 & $\begin{array}{l}\begin{array}{l}\text { constructing and operating technical consultation and agricultural engineering } \\
\text { companies }\end{array} \\
\end{array}$ \\
\hline 142 & 2 & $\begin{array}{l}\text { Construction of mechanized service provider companies as well as different clinics for } \\
\text { phytopathology, veterinary, soil and water and plant protection }\end{array}$ \\
\hline 143 & 2 & $\begin{array}{l}\text { Cooperatives for breeding the seedlings of non-fruitful tress (construction of plant } \\
\text { nursery) }\end{array}$ \\
\hline 144 & 3 & Machine-made brick project \\
\hline 145 & 3 & Development of industrial and medicinal plants \\
\hline 146 & 3 & Production of forest and posture seedlings \\
\hline 147 & 4 & Cooperatives for production of vegetables and summer crops \\
\hline 148 & 4 & Cooperatives for production of natural and decorative flowers \\
\hline 149 & 5 & Execution of forestry projects \\
\hline 150 & 5 & Execution of Watershed operations in exempt lands \\
\hline 151 & 6 & $\begin{array}{l}\text { Designing and developing fruit gardens and greenhouse products-construction of plant } \\
\text { nursery }\end{array}$ \\
\hline 152 & 6 & $\begin{array}{l}\text { Providing mechanized services (executing planting, growing and harvesting } \\
\text { operations) }\end{array}$ \\
\hline 153 & 6 & Home-scaled agricultural small projects \\
\hline 154 & 6 & Small-scaled agricultural processing industries \\
\hline 155 & 7 & Employment of rural women \\
\hline 156 & 7 & Cooperatives for procurement and distribution of agricultural inputs and machineries \\
\hline 157 & 8 & Cooperatives for procurement and distribution of plants, flowers and seedlings \\
\hline 158 & 8 & Cooperatives for providing mechanized services to farmers \\
\hline 159 & 8 & Cooperative for production of cereals (wheat and barley) \\
\hline 160 & 8 & Cooperatives for production of fruitful and non-fruitful trees \\
\hline 161 & 1 & $\begin{array}{l}\text { Cooperatives for production of greenhouse summer crops (constructing greenhouse } \\
\text { and producing greenhouse products) }\end{array}$ \\
\hline 162 & 1 & Cooperatives for production and distribution of agricultural services institutes \\
\hline 163 & 2 & Cooperatives for industries associated with agricultural products \\
\hline 164 & 2 & Cooperative of small markets for direct supply of machineries \\
\hline 165 & 2 & Cooperatives for producing and breeding silkworm \\
\hline
\end{tabular}




\begin{tabular}{|r|r|l|}
\hline \multicolumn{1}{|c|}{ code } & $\begin{array}{c}\text { Interview } \\
\text { no. }\end{array}$ & \multicolumn{1}{|c|}{ Executable project } \\
\hline 166 & 3 & Cooperatives for honey production (beekeepers cooperatives) \\
\hline 167 & 3 & Cooperatives for milk collection centers \\
\hline 168 & 4 & $\begin{array}{l}\text { Cooperatives for production of forestry and posture subsidiary products (tragacanth } \\
\text { and pistacia) }\end{array}$ \\
\hline 169 & 4 & Fighting plant diseases and pests \\
\hline 170 & 5 & Maintenance of agricultural machineries and tools (training and maintenance) \\
\hline 171 & 6 & Studying, designing and executing pressurized irrigation systems \\
\hline 172 & 6 & Establishing pedology and hydrology laboratories \\
\hline 173 & 6 & Establishing laboratories for evaluating plant diseases and pests \\
\hline 174 & 7 & Producing and distributing modified seedling seeds required for the studied region \\
\hline 175 & 7 & Supplying and selling agricultural machineries, tools and inputs \\
\hline 176 & 7 & $\begin{array}{l}\text { Establishing contractual companies for providing engineering services in the field of } \\
\text { technical and infrastructure issues }\end{array}$ \\
\hline 177 & 8 & Production of fodder (planting and growing fodder plants) \\
\hline 178 & 8 & Construction of seed hubs and production of agricultural seeds \\
\hline 179 & 8 & Industrial milk industries \\
\hline 180 & 8 & Production of livestock food and seed sifting stations (stationary and mobile stations) \\
\hline 181 & 8 & Fodder production \\
\hline
\end{tabular}

The above table encodes the propositions derived from specialists' interview

Table 2: Allocating joint codes to executable projects

\begin{tabular}{|c|c|c|c|}
\hline Executable p[projects & Joint code & Executable projects & Joint code \\
\hline $\begin{array}{c}100-101-102-103-104-105-106- \\
107-108\end{array}$ & $\begin{array}{l}\text { Plant product } \\
\text { projects }\end{array}$ & $109-110-111$ & $\begin{array}{l}\text { Livestock product } \\
\text { projects }\end{array}$ \\
\hline $\begin{array}{l}112-113-114-115-116-117-118- \\
119-120-121-122-123-124-125- \\
126-127-128-129-130-131-132\end{array}$ & $\begin{array}{l}\text { Water, soil and } \\
\text { industries }\end{array}$ & $\begin{array}{c}133-134-135-136- \\
137-138-139-140\end{array}$ & Veterinary medicine \\
\hline $\begin{array}{c}141-142-143-149-150-151-152- \\
153-154-155\end{array}$ & $\begin{array}{c}\text { Forest, posture and } \\
\text { watershed } \\
\text { management }\end{array}$ & $144-145-146-147-148$ & $\begin{array}{l}\text { Promotion and } \\
\text { exploitation }\end{array}$ \\
\hline $\begin{array}{c}156-157-158-159-160-161-162- \\
163-164-165-166-167-168\end{array}$ & $\begin{array}{c}\text { Economic } \\
\text { associations }\end{array}$ & $\begin{array}{l}169-170-171-172- \\
173-174-175-176\end{array}$ & $\begin{array}{c}\text { Cooperatives for } \\
\text { agricultural engineering } \\
\text { services }\end{array}$ \\
\hline 177-178-179-180-181 & & $\begin{array}{l}\text { Small job } \\
\text { opportunities in } \\
\text { agriculture sector }\end{array}$ & \\
\hline
\end{tabular}

Table 2 shows joint codes of executable projects.

Regarding plant product projects, 9 proposals were identified. Mean and confirmatory factor analysis were used to assess their importance, executability and priority. 
Bulletin de la Société Royale des Sciences de Liège, Vol. 86, special edition, 2017, p. 794 - 807

Table 3: statistical analysis results

\begin{tabular}{|c|c|c|c|c|c|c|}
\hline class & Identified projects & mean & $\begin{array}{c}\text { Factor } \\
\text { load }\end{array}$ & $\begin{array}{l}\text { Sig. } \\
\text { level }\end{array}$ & result & priority \\
\hline \multirow[t]{9}{*}{$\begin{array}{l}\text { Plant products } \\
\text { affairs }\end{array}$} & $\begin{array}{l}\text { Construction and development of aquatic } \\
\text { and dry land gardens }\end{array}$ & 3.29 & 0.83 & 9.01 & executable & 4 \\
\hline & $\begin{array}{l}\text { Modification, replacement and renovation } \\
\text { of gardens }\end{array}$ & 3.52 & 0.88 & 9.95 & executable & 1 \\
\hline & Production of certified seedling & 3.28 & 0.86 & 9.52 & executable & 5 \\
\hline & $\begin{array}{l}\text { Construction of flower, vegetable and } \\
\text { summer crop greenhouses }\end{array}$ & 3.12 & 0.79 & 8.35 & executable & 7 \\
\hline & $\begin{array}{c}\text { Optimizing, renovating and equipping } \\
\text { greenhouses }\end{array}$ & 3.34 & 0.81 & 8.66 & executable & 3 \\
\hline & $\begin{array}{l}\text { Production and collection of medicinal } \\
\text { plants and planting medicinal herbs }\end{array}$ & 3.48 & 0.78 & 8.20 & executable & 2 \\
\hline & $\begin{array}{c}\text { Constructing, equipping and developing } \\
\text { mechanized agricultural units }\end{array}$ & 3.18 & 0.76 & 7.99 & executable & 6 \\
\hline & $\begin{array}{c}\text { Development of rice seedling banks and } \\
\text { production of rice hybrid seed }\end{array}$ & 3.03 & 0.71 & 7.19 & executable & 9 \\
\hline & $\begin{array}{c}\text { Development of summer crop seedling } \\
\text { banks and production of hybrid seeds of } \\
\text { vegetables and summer crops }\end{array}$ & 3.11 & 0.73 & 7.56 & executable & 8 \\
\hline
\end{tabular}

Table 4: Statistical analysis results

\begin{tabular}{|c|c|c|c|c|c|c|}
\hline class & Identified projects & mean & $\begin{array}{l}\text { Factor } \\
\text { load }\end{array}$ & $\begin{array}{l}\text { Sig. } \\
\text { level }\end{array}$ & result & priority \\
\hline \multirow{3}{*}{$\begin{array}{l}\text { livestock } \\
\text { products } \\
\text { affairs }\end{array}$} & $\begin{array}{l}\text { Construction of honey bee queen } \\
\text { breeding units }\end{array}$ & 3.24 & 0.59 & 9.75 & executable & 3 \\
\hline & $\begin{array}{l}\text { Construction of silkworm production } \\
\text { units, construction of mobile centers for } \\
\text { milk collection }\end{array}$ & 3.90 & 0.95 & 15.49 & executable & 1 \\
\hline & $\begin{array}{l}\text { Construction of complementary and } \\
\text { processing units subsidiary to plant } \\
\text { products including packing, preservation } \\
\text { and freezing different cereals, vegetables, } \\
\text { citrus, agricultural products, different } \\
\text { fruit juices and cold storage facilities }\end{array}$ & 3.40 & 0.73 & 11.92 & executable & 2 \\
\hline
\end{tabular}


Bulletin de la Société Royale des Sciences de Liège, Vol. 86, special edition, 2017, p. 794 - 807

Table 5: Statistical analysis results

\begin{tabular}{|c|c|c|c|c|c|c|}
\hline Class & Identified projects & mean & $\begin{array}{c}\text { Factor } \\
\text { load }\end{array}$ & $\begin{array}{l}\text { Sig. } \\
\text { level }\end{array}$ & result & priority \\
\hline \multirow{21}{*}{ 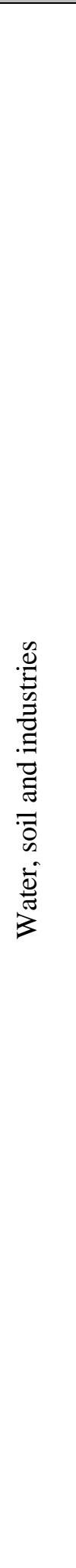 } & Tannery and hide projects & 1.58 & 0.41 & 1.58 & $\begin{array}{l}\text { Non- } \\
\text { executable }\end{array}$ & \\
\hline & $\begin{array}{l}\text { Beverage and non-natural (essence) } \\
\text { fruit juice industries }\end{array}$ & 1.86 & 0.30 & 1.23 & $\begin{array}{l}\text { Non- } \\
\text { executable }\end{array}$ & \\
\hline & Wooden product industries & 3.22 & 0.83 & 9.21 & executable & 2 \\
\hline & Gas station & 2.25 & 0.43 & 1.64 & $\begin{array}{l}\text { Non- } \\
\text { executable }\end{array}$ & \\
\hline & Bitumen and asphalt industry & 1.78 & 0.35 & 1.21 & $\begin{array}{l}\text { Non- } \\
\text { executable }\end{array}$ & \\
\hline & Metal melting & 1.81 & 0.32 & 1.58 & $\begin{array}{l}\text { Non- } \\
\text { executable }\end{array}$ & \\
\hline & Confectionary and cookie industry & 3.38 & 0.88 & 9.96 & executable & 1 \\
\hline & $\begin{array}{l}\text { Livestock and poultry industrial } \\
\text { slaughterhouse }\end{array}$ & 1.53 & 0.41 & 1.56 & $\begin{array}{l}\text { Non- } \\
\text { executable }\end{array}$ & \\
\hline & Meat packing and meat products & 2.32 & 0.36 & 1.38 & $\begin{array}{l}\text { Non- } \\
\text { executable }\end{array}$ & \\
\hline & $\begin{array}{l}\text { Making compost out of municipally } \\
\text { wastes }\end{array}$ & 1.84 & 0.24 & 1.01 & $\begin{array}{l}\text { Non- } \\
\text { executable }\end{array}$ & \\
\hline & Making compost out of livestock dung & 2.01 & 0.38 & 1.32 & $\begin{array}{l}\text { Non- } \\
\text { executable }\end{array}$ & \\
\hline & Industrial oil refining project & 2.01 & 0.40 & 1.55 & $\begin{array}{l}\text { Non- } \\
\text { executable }\end{array}$ & \\
\hline & Edible oil refining project & 2.15 & 0.42 & 1.69 & $\begin{array}{l}\text { Non- } \\
\text { executable }\end{array}$ & \\
\hline & $\begin{array}{l}\text { Brick and ready-mix concrete } \\
\text { production project }\end{array}$ & 3.08 & 0.77 & 8.16 & executable & 3 \\
\hline & $\begin{array}{l}\text { Building packed plaster and lime } \\
\text { products }\end{array}$ & 2.20 & 0.44 & 1.64 & $\begin{array}{l}\text { Non- } \\
\text { executable }\end{array}$ & \\
\hline & Production of plastic and rubber parts & 2.00 & 0.40 & 1.57 & $\begin{array}{l}\text { Non- } \\
\text { executable }\end{array}$ & \\
\hline & Human medicine industry & 2.24 & 0.19 & 1.09 & $\begin{array}{l}\text { Non- } \\
\text { executable }\end{array}$ & \\
\hline & $\begin{array}{l}\text { Livestock and aquatic animals } \\
\text { medicine industry }\end{array}$ & 2.19 & 0.25 & 1.14 & $\begin{array}{l}\text { Non- } \\
\text { executable }\end{array}$ & \\
\hline & Production of vehicle parts & 2.15 & 0.37 & 1.28 & $\begin{array}{l}\text { Non- } \\
\text { executable }\end{array}$ & \\
\hline & Production of vehicle plastic parts & 1.81 & 0.28 & 1.32 & $\begin{array}{l}\text { Non- } \\
\text { executable }\end{array}$ & \\
\hline & $\begin{array}{l}\text { Production of paint and chemical } \\
\text { substances }\end{array}$ & 1.56 & 0.36 & 1.39 & $\begin{array}{l}\text { Non- } \\
\text { executable }\end{array}$ & \\
\hline
\end{tabular}


Table 6: Statistical analysis

\begin{tabular}{|c|c|c|c|c|c|c|}
\hline Class & Identified projects & mean & $\begin{array}{c}\text { Factor } \\
\text { load }\end{array}$ & $\begin{array}{l}\text { Sig. } \\
\text { level }\end{array}$ & result & priority \\
\hline \multirow{8}{*}{ 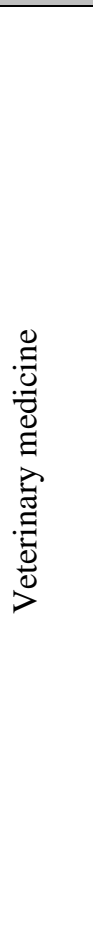 } & $\begin{array}{l}\text { Construction of complementary and processing units } \\
\text { subsidiary to livestock products, cold storage } \\
\text { facilities, processing and packing different kinds of } \\
\text { red meat, white meat and dairy products }\end{array}$ & 3.69 & 0.96 & 10.64 & executable & 1 \\
\hline & $\begin{array}{l}\text { Construction of complementary and processing units } \\
\text { subsidiary to fishery products, including processing, } \\
\text { freezing, producing and cold storage facilities, } \\
\text { processing and packing different kinds of fishes, } \\
\text { shrimps and can products }\end{array}$ & 3.48 & 0.93 & 10.41 & executable & 2 \\
\hline & Cattle breeding project (less than 25 cattle) & 3.22 & 0.44 & 1.77 & $\begin{array}{l}\text { Non- } \\
\text { executable }\end{array}$ & \\
\hline & Cattle breeding project (more than 25 cattle) & 2.25 & 0.42 & 1.92 & $\begin{array}{l}\text { Non- } \\
\text { executable }\end{array}$ & \\
\hline & Egg-laying chicken breeding (10000 parts and more) & 1.78 & 0.34 & 1.31 & $\begin{array}{l}\text { Non- } \\
\text { executable }\end{array}$ & \\
\hline & Cold water and warm water fish breeding & 3.26 & 0.61 & 8.33 & executable & 3 \\
\hline & Industrial cattle breeding (200 cattle) & 3.38 & 0.47 & 1.94 & $\begin{array}{l}\text { Non- } \\
\text { executable }\end{array}$ & \\
\hline & Industrial cattle breeding (200 cattle) & 1.53 & 0.39 & 1.65 & $\begin{array}{l}\text { Non- } \\
\text { executable }\end{array}$ & \\
\hline
\end{tabular}

Table 7: Statistical analysis

\begin{tabular}{|c|c|c|c|c|c|c|}
\hline Class & Identified projects & mean & $\begin{array}{c}\text { Factor } \\
\text { load }\end{array}$ & $\begin{array}{l}\text { Sig. } \\
\text { level }\end{array}$ & result & priority \\
\hline \multirow{10}{*}{ 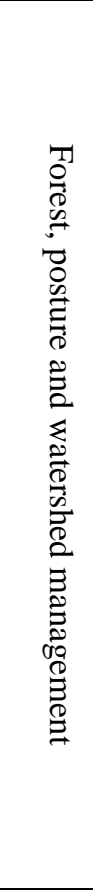 } & $\begin{array}{l}\text { Establishing and operating consulting companies for } \\
\text { providing technical and agricultural engineering } \\
\text { services }\end{array}$ & 3.49 & 0.79 & 11.15 & executable & 5 \\
\hline & $\begin{array}{c}\text { Establishing companies for providing mechanized } \\
\text { services and establishing different phytopathology, } \\
\text { veterinary, soil and water and plant protection } \\
\text { clinics }\end{array}$ & 3.01 & 0.59 & 9.23 & executable & 10 \\
\hline & $\begin{array}{l}\text { Cooperatives for producing the seedling of fruitful } \\
\text { and non-fruitful trees (plant nursery) }\end{array}$ & 3.57 & 0.71 & 11.42 & executable & 4 \\
\hline & Executing forestry projects & 4.03 & 0.94 & 12.34 & executable & 1 \\
\hline & $\begin{array}{l}\text { Executing watershed management operations in } \\
\text { exempt lands }\end{array}$ & 3.68 & 0.87 & 11.67 & executable & 3 \\
\hline & $\begin{array}{l}\text { Designing and developing fruit gardens and } \\
\text { greenhouse products and constructing plant nursery }\end{array}$ & 3.03 & 0.65 & 9.76 & executable & 9 \\
\hline & $\begin{array}{l}\text { Providing mechanized services (performing } \\
\text { planting, growing and harvesting processes) }\end{array}$ & 3.27 & 0.73 & 10.12 & executable & 8 \\
\hline & Home-scaled small agricultural projects & 3.42 & 0.77 & 10.57 & executable & 6 \\
\hline & Small agricultural processing projects & 3.38 & 0.74 & 10.43 & executable & 7 \\
\hline & Employment of rural women & 3.78 & 0.89 & 12.27 & executable & 2 \\
\hline
\end{tabular}


Table 8: Statistical analysis

\begin{tabular}{|c|c|c|c|c|c|c|}
\hline class & Identified projects & mean & $\begin{array}{c}\text { Factor } \\
\text { load }\end{array}$ & $\begin{array}{l}\text { Sig. } \\
\text { level }\end{array}$ & result & priority \\
\hline \multirow{5}{*}{ 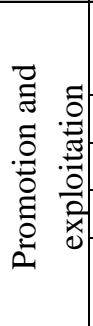 } & $\begin{array}{l}\text { Cooperatives for producing the seedling of non- } \\
\text { fruitful trees (plant nursery) }\end{array}$ & 3.00 & 0.56 & 8.54 & executable & 5 \\
\hline & Production of machine-made brick & 3.73 & 0.92 & 12.24 & executable & 2 \\
\hline & Development of medicinal and industrial plants & 3.75 & 0.93 & 12.42 & executable & 1 \\
\hline & Production of forest and posture seedlings & 3.28 & 0.68 & 9.84 & executable & 4 \\
\hline & $\begin{array}{l}\text { Cooperatives for production of vegetables and } \\
\text { summer crops }\end{array}$ & 3.35 & 0.70 & 9.98 & executable & 3 \\
\hline
\end{tabular}

Table 9: Statistical analysis results

\begin{tabular}{|c|c|c|c|c|c|c|}
\hline class & Identified project & mean & $\begin{array}{c}\text { Factor } \\
\text { load }\end{array}$ & $\begin{array}{l}\text { Sig. } \\
\text { level }\end{array}$ & result & priority \\
\hline \multirow{13}{*}{ 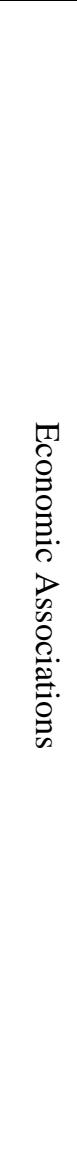 } & $\begin{array}{l}\text { Cooperatives for procurement and distribution of } \\
\text { agricultural inputs and machineries }\end{array}$ & 3.09 & 0.70 & 9.92 & executable & 10 \\
\hline & $\begin{array}{l}\text { Cooperative for procurement and distribution of } \\
\text { different seedlings, flowers and plants }\end{array}$ & 3.33 & 0.83 & 10.72 & executable & 5 \\
\hline & $\begin{array}{l}\text { Cooperatives for providing mechanized services to } \\
\text { farmers }\end{array}$ & 3.54 & 0.86 & 11.21 & executable & 3 \\
\hline & $\begin{array}{l}\text { Cooperatives for production of cereals (wheat and } \\
\text { barley) }\end{array}$ & 3.30 & 080 & 10.33 & executable & 6 \\
\hline & $\begin{array}{l}\text { Cooperatives for production of fruitful and non- } \\
\text { fruitful trees }\end{array}$ & 3.63 & 0.89 & 11.38 & executable & 2 \\
\hline & $\begin{array}{l}\text { Cooperatives for production of greenhouse summer } \\
\text { crops (construction and of greenhouse and } \\
\text { production of greenhouse products) }\end{array}$ & 3.21 & 0.79 & 10.63 & executable & 7 \\
\hline & $\begin{array}{l}\text { Cooperatives for procurement and distribution of } \\
\text { agricultural inputs }\end{array}$ & 3.00 & 0.55 & 9.77 & executable & 12 \\
\hline & $\begin{array}{l}\text { Cooperatives for industries associated with } \\
\text { agricultural products }\end{array}$ & 3.20 & 0.77 & 10.57 & executable & 8 \\
\hline & $\begin{array}{l}\text { Cooperatives of small markets for direct supply of } \\
\text { machineries }\end{array}$ & 2.68 & 0.31 & 1.69 & $\begin{array}{l}\text { Non- } \\
\text { executable }\end{array}$ & 13 \\
\hline & Cooperatives for producing and breeding silkworm & 3.17 & 0.73 & 10.37 & executable & 9 \\
\hline & $\begin{array}{l}\text { Cooperatives for production of honey (beekeeper } \\
\text { cooperatives) }\end{array}$ & 3.74 & 0.89 & 11.88 & executable & 1 \\
\hline & Cooperatives for milk collection & 3.04 & 0.63 & 9.83 & executable & 11 \\
\hline & $\begin{array}{l}\text { Cooperatives for production of subsidiary products } \\
\text { of posture and forestry (tragacanth and pistacia) }\end{array}$ & 3.53 & 0.85 & 10.94 & executable & 4 \\
\hline
\end{tabular}


Table 10: Statistical analysis results

\begin{tabular}{|c|c|c|c|c|c|c|}
\hline class & Identified project & mean & $\begin{array}{c}\text { Factor } \\
\text { load }\end{array}$ & $\begin{array}{l}\text { Sig. } \\
\text { level }\end{array}$ & result & priority \\
\hline \multirow[t]{8}{*}{$\begin{array}{l}\text { Production } \\
\text { cooperatives }\end{array}$} & Fighting plant diseases and pests & 2.36 & 0.21 & 1.06 & $\begin{array}{l}\text { Non- } \\
\text { executable }\end{array}$ & 8 \\
\hline & $\begin{array}{l}\text { Maintenance of agricultural tools and } \\
\text { machineries (training and maintenance) }\end{array}$ & 3.03 & 0.77 & 9.62 & executable & 7 \\
\hline & $\begin{array}{c}\text { Studying, designing and executing } \\
\text { pressurized irrigation systems }\end{array}$ & 3.69 & 0.73 & 11.45 & executable & 1 \\
\hline & $\begin{array}{c}\text { Establishing pedology and hydrology } \\
\text { laboratories }\end{array}$ & 3.63 & 0.85 & 10.87 & executable & 2 \\
\hline & $\begin{array}{l}\text { Establishing laboratories for } \\
\text { investigating plant diseases and pests }\end{array}$ & 3.10 & 0.82 & 9.98 & executable & 6 \\
\hline & $\begin{array}{c}\text { Production and distribution of modified } \\
\text { seedling seeds required for the studied } \\
\text { region }\end{array}$ & 3.35 & 0.80 & 10.63 & executable & 4 \\
\hline & $\begin{array}{l}\text { Procurement and selling agricultural } \\
\text { inputs, tools and machineries }\end{array}$ & 3.40 & 0.83 & 10.75 & executable & 3 \\
\hline & $\begin{array}{l}\text { Establishing contractual companies for } \\
\text { providing engineering services in the } \\
\text { field of technical and infrastructure } \\
\text { issues }\end{array}$ & 3.25 & 0.60 & 10.47 & executable & 5 \\
\hline
\end{tabular}

Table 11: Statistical analysis results

\begin{tabular}{|c|c|c|c|c|c|c|}
\hline class & Identified project & mean & $\begin{array}{l}\text { Factor } \\
\text { load }\end{array}$ & $\begin{array}{l}\text { Sig. } \\
\text { level }\end{array}$ & result & priority \\
\hline \multirow[t]{5}{*}{$\begin{array}{l}\text { Small } \\
\text { opportunities }\end{array}$} & $\begin{array}{l}\text { Fodder production (planting and } \\
\text { producing fodder plants) }\end{array}$ & 3.32 & 0.94 & 13.06 & executable & 1 \\
\hline & $\begin{array}{l}\text { construction of seed bank, production of } \\
\text { agricultural seeds }\end{array}$ & 3.30 & 0.96 & 13.15 & executable & 2 \\
\hline & Industrial milk industries & 2.34 & 0.46 & 1.45 & $\begin{array}{l}\text { Non- } \\
\text { executable }\end{array}$ & \\
\hline & $\begin{array}{l}\text { Production of livestock and poultry food } \\
\text { and seed sifting stations (stationary and } \\
\text { mobile stations) }\end{array}$ & 3.01 & 0.63 & 9.35 & executable & 3 \\
\hline & Fodder production & 2.86 & 0.6 & 9.15 & executable & \\
\hline
\end{tabular}

\section{Conclusion}

The following table concludes the final analysis results with respect to considered classifications.

Table 12: results

\begin{tabular}{|l|r|r|r|}
\hline classification & Number of proposals & Executable & Non-executable \\
\hline Plant products & 9 & 9 & - \\
\hline
\end{tabular}




\begin{tabular}{|l|r|r|r|}
\hline Livestock products & 3 & 3 & - \\
\hline Water, soil and industries & 21 & 3 & 18 \\
\hline Veterinary medicine & 8 & 3 & 5 \\
\hline Forest, posture and watershed management & 10 & 10 & - \\
\hline Promotion and exploitation & 5 & 5 & - \\
\hline Economic associations & 13 & 13 & 1 \\
\hline Production cooperatives & 8 & 7 & 1 \\
\hline Job opportunities & 5 & 4 & \\
\hline
\end{tabular}

According to above classifications, plant product and livestock product projects are executable in 9 and 3 classes, respectively. Regarding water, soil and industry projects, of 21 studied classes only 3 projects were recognized as executable projects (wooden product industries, confectionary and cookie industry and brick and ready-mix concrete industry). In veterinary medicine field, of 10 studied classes 3 classes were executable as follows: construction of complementary and processing industries subsidiary to livestock products, cold storage facility, processing and packing red and white meats and dairy products; construction of complementary and processing industries subsidiary to fishery including processing, freezing, producing and packing different fishes, shrimps and can products and breeding cold water fishes with more than $93 \%$ factor load and and warm water fishes with more than $60 \%$ factor load; indicating that necessary measures should be taken into account during the execution of the projects. All 10 classes of forest, posture and watershed management projects were recognized executable. The same is valid in the promotion and exploitation projects and economic association projects consisting of 5 and 13 classes, respectively. Regarding production cooperatives, of 8 proposed projects only the project of fighting plant diseases and pests was recognized as non-executable project with a low factor load. In job-opportunities filed, of 5 proposed projects only industrial milk industries was recognized as non-executable project.

\section{Study limitations}

The researcher faced several limitations in this study; some roots in the nature of scientific studies in human field, which are inevitable. Limited resources and limited studies on the identification of development projects in Iran and the world dams in terms of their contribution to human field contamination were other limitations of this study.

\section{References}

[1] Iran Statistical Center (2003), "the results of investigations on the environmental impacts of industry and mine activities from stat. point of view, 2000

[2] environment and sustainable development office of the Ministry of Agriculture Jahad (2003), agriculture and the global year of drinking water, bulletin No. 11, sustainable development committee 
[3] Sheibani Behzad (2013), investigation of the environmental impacts in irrigation and drainage networks, the first national congress of agricultural water resource challenges, Iranian Association for Irrigation and Drainage association, Isfahan

[4] Dizaji. Monire, Gholaminezhad Dizgare. Solmaz (2011), "economic growth, human development and water pollution arising from economic activities of the selected countries of the world", applied economy quarterly. Year 3, no. 11

[5] Ahmadi. Ali, Hajinezhad. Ali, (2010), "environment depletion a hurdle in the way of sustainable development", articles of the 4th international congress of the geographers of Islam world, Zahedan, April 13-15

[6] Karamouz. Mohammad, Eliasi. Asghar, Ahmadinia. Saleh (2007), "economic facilitation of the effect of demand management on water resource development plans, case study", civil engineering, Islamic Azad University publications, year $1, \mathrm{n}^{\circ} .2$ 